Article

\title{
Application of the Natural Products NOZEMAT HERB and NOZEMAT HERB PLUS Can Decrease Honey Bee Colonies Losses during the Winter
}

\author{
Rositsa Shumkova ${ }^{1}$, Ralitsa Balkanska ${ }^{2}$, Tsvetoslav Koynarski ${ }^{3}$ and Peter Hristov ${ }^{4, *(D)}$ \\ 1 Research Centre of Stockbreeding and Agriculture, Agricultural Academy, 4700 Smolyan, Bulgaria; \\ rositsa6z@abv.bg \\ 2 Department "Special Branches", Institute of Animal Science, Agricultural Academy, \\ 2230 Kostinbrod, Bulgaria; r.balkanska@gmail.com \\ 3 Department of Animal Genetics, Faculty of Veterinary Medicine, Trakia University, \\ 6000 Stara Zagora, Bulgaria; tkoynarski@gmail.com \\ 4 Department of Animal Diversity and Resources, Institute of Biodiversity and Ecosystem Research, \\ Bulgarian Academy of Sciences, 1113 Sofia, Bulgaria \\ * Correspondence: peter_hristoff@abv.bg; Tel.: +359-2-979-2327
}

Citation: Shumkova, R.; Balkanska,

R.; Koynarski, T.; Hristov, P.

Application of the Natural Products NOZEMAT HERB and NOZEMAT HERB PLUS Can Decrease Honey Bee Colonies Losses during the Winter. Diversity 2021, 13, 228. https:// doi.org/10.3390/d13060228

Academic Editor: Miguel Ferrer

Received: 29 April 2021

Accepted: 21 May 2021

Published: 23 May 2021

Publisher's Note: MDPI stays neutral with regard to jurisdictional claims in published maps and institutional affiliations.

Copyright: (c) 2021 by the authors. Licensee MDPI, Basel, Switzerland. This article is an open access article distributed under the terms and conditions of the Creative Commons Attribution (CC BY) license (https:// creativecommons.org/licenses/by/ $4.0 /)$.
Abstract: Honey bees (Apis mellifera L.) are crucial pollinators for many crops and natural ecosystems. However, honey bee colonies have been experiencing heavy overwinter mortality in almost all parts of the world. In the present study we have investigated, for the first time, the effects from the application of the herbal supplements NOZEMAT HERB ${ }^{\circledR}(\mathrm{NH})$ and NOZEMAT HERB PLUS ${ }^{\circledR}$ (NHP) on overwintering honey bee colony survival and on total protein and lysozyme content. To achieve this, in early autumn 2019, 45 colonies were selected and treated with these herbal supplements. The total protein and lysozyme content were evaluated after administration of $\mathrm{NH}$ and NHP twice the following year (June and September 2020). The obtained results have shown that both supplements have a positive effect on overwintering colony survival. Considerable enhancement in longevity of "winter bees" has been observed after the application of NHP, possibly due to the increased functionality of the immune system and antioxidant detoxification capacity. Although the mechanisms of action of NH and NHP are yet to be completely elucidated, our results suggest a new holistic approach on overwintering honey bee colony survival and welfare.

Keywords: honey bee colony survival; overwintering; plant extract; biochemical markers; antioxidant capacity

\section{Introduction}

Honey bees (Apis mellifera L.) are widely considered to be the most important insects in the world. Bees are the most essential pollinators of plant species in natural and agricultural ecosystems [1]. Moreover, many honey bee products have nutraceutical significance, which makes them invaluable to human health and wealth [2,3].

Honey bees survive under various environmental conditions and large climate changes. Winter is the greatest challenge to honey bee colonies in different regions all over the world. Although honey bees are well-adapted to survive winter conditions, winter losses are emerging as the most serious threat for beekeeping. A large-scale survey covering 35 countries, which was conducted in the winter of 2018-2019, showed that overall loss rates per winter vary considerably between countries [4]. The highest winter losses (32.0\%) were detected in Slovenia, while Bulgaria revealed the lowest loss rate (5.8\%). In Serbia the loss rate for winter 2018/19 was 25.4\%, followed by Spain, Croatia, Iran, Greece, and Portugal, where winter colony losses were between $20 \%$ and $25 \%$. In addition, moderate winter losses were recorded in Scotland and Italy (18.9\% and $16.5 \%$, respectively) within this survey [4]. 
Different researchers have pointed out numerous factors as the main reasons for the winter colony losses and have proposed various approaches to overcome this problem. Here we will try to summarize these briefly.

\subsection{Queen Bee Management}

Queen bees' age and health status are among the most important factors for the successful overwintering of bee colonies. However, problems with queen bees can occur due to various circumstances, such as biological causes or poor beekeeping management practices $[5,6]$. The age of the queen bees going into winter is important for winter colony survival $[7,8]$. It has been observed that honey bee colony mortality during the winter decreases with an increase in the percentage of young queens $[4,9,10]$. Additionally, queen problems, mainly during the summer, such as young queens failing, superseded queens, queens "disappearing", queen introduction, etc., increase the probability of overwinter colony loss [9-11].

\subsection{Beekeeping Management Practices}

While some variable factors are outside of beekeepers' control (e.g., weather, external pesticide applications, habitat quality), others are directly related to beekeeping management practices and beekeepers' professionalism $[6,12,13]$. It has been found that migratory beekeeping, compared to non-migrating operations, reduced winter colony losses [10,14]. The main reasons for this are that migratory beekeepers have more experience and migrated colonies have access to better foraging sources. Another, very important factor for honey bee health turns out to be the origin of the beeswax used in the beekeeping operation. It has been observed that beekeepers who have purchased wax outside from their apiary registered a higher winter loss rate compared to beekeepers using only their own beeswax [10]. It has been found that beeswax, as a natural honey bee product, can accumulate various pesticides, honey bee-associated viruses, American foulbrood spores, veterinary drug residues, etc. [15-17]. The presence of pesticides in beeswax poses a serious threat to bee colonies survival during the winter; therefore beeswax is usually heat-treated, which eliminates the various pathogens contained in it. A trend for lower winter losses has been observed when about $30 \%$ of old brood frames were replaced with new ones [10].

It is interesting to note the differences regarding honey bee winter survival in organic beekeeping compared to nonorganic practices. As practices such as using sugar for feeding, treatment against various diseases, and purchasing wax combs are not allowed in organic beekeeping [18,19], greater losses of bee colonies should be expected. On the other hand, certificated organic apiaries are usually located in isolated places, which reduces the possibility of various pathogens affecting bee colonies, compared to conventional beekeeping. The results of the conducted studies so far have not reflected a significant difference regarding winter bee losses in organic and nonorganic beekeeping, which requires further research in this direction.

\subsection{Forage Sources as a Risk Factor for Honey Bee Winter Losses}

Forage sources are among the most important factors for the successful wintering of bee colonies $[20,21]$. It has been found that certain forage sources can have a significant effect on honey bee winter survival. For example, there is direct evidence that maize is not a suitable forage source for honey bees [22,23]. The main reason for this is, presumably, the accumulation of pesticides in the collected pollen or guttation water during treatment of maize fields, which may lead to chronic pesticide exposure, higher loss rate, and hence, reduced winter bee survival [22,24]. As maize is one of the main crops in the world, this problem can persist for many years [25].

Other crops discussed in relation to higher winter bee mortality are sunflower and oilseed rape. Considering sunflower crops, higher colony losses have been observed during some years $[23,26,27]$, while in others such have not been reported, even in case of treatment of sunflower seeds with insecticides [28]. Therefore, the question of the impact 
of sunflowers on winter colony losses remains unresolved. The oilseed rape is a suitable food source for bees not only because of the large amount of nectar and pollen, but because it blooms in spring and is the first major food source. Unfortunately, this crop, like maize, poses a danger to bees, as it is usually treated with various insecticides [29,30].

The so-called Autumn Forage Crops (AFC, intended as melliferous crops after flowering of the main honey vegetation) pose probably the biggest threat of honey bee losses during the winter. The purpose of planting these crops is extending the active season; however they can be dangerous due to bees' prolonged exposure to the ectoparasitic mite Varroa destructor and to honey bee-associated viruses transmitted by the latter [23]. There is also an increased risk of weakening the colonies and higher winter losses.

Finally, it has been observed that the melezitose forage, which comes from honeydew (a sugar-rich, sticky liquid, secreted by Aphids insects) is associated with significant losses of bee colonies in the winter [31,32]. The problem of using melezitose as a food source is related, on the one hand, to the difficult removing of melezitose honey from the comb cells, and on the other hand, to the fact that bees are able to absorb a very small part of it in comparison with sucrose [33]. This can lead to significant nutritional stress when overwintering.

\subsection{Role of Pathogens on Honey Bee Winter Losses}

A large number of pathogens and parasites, often in coinfections, pose serious threats to honey bee health and survival. The ectoparasitic mite Varroa destructor poses the biggest threat to the survival of honey bee colonies in winter [34-36]. A number of different techniques of treating bee colonies have been developed to prevent the devastating losses caused by $V$. destructor. These include the use of natural compounds such as formic acid [37], oxalic acid [38], beta acids from hops (Humulus lupulus) [39], and essential oils (thymol) [40]. Other approaches are associated with physical methods—drone brood removal, screened bottom board and powdered sugar [41], or reducing pest reproduction-mite-resistant colonies selection, small-hexagon cell comb and brood break [42]. Finally, for chemical control of Varroa mites, various synthetic acaricides/miticides (amitraz, flumethrin and coumaphos) are used $[43,44]$. The disadvantages of the administration of these compounds include the risk of residue accumulation in the beeswax $[45,46]$ and Varroa mite crossresistance to acaricides $[35,47]$. In order to control $V$. destructor infestation and reduce bee losses in winter, it is important to consider during which period the bee colonies will be treated and which of the above methods will be chosen. In this regard, it has been found that summer treatments with formic acid in August or with Thymovar in July and in warm Augusts, or with Apilife (thymol) in July and Apivar (amitraz) between July and September can lead to low honey bee colony losses [35]. Additionally, oxalic acid application in December is also recommended. Removal of the drone brood in April has been associated with reduced colony losses as well [35].

A large number of studies have highlighted the link between honey bee-associated viruses and winter losses in bee colonies [48-51]. For example, two long-term studies carried out in Germany and USA have shown that IAPV (Israeli acute paralysis virus) and ABPV (Acute bee paralysis virus) are involved in winter colony losses [52,53]. In Switzerland, it has been observed that ABPV and DWV (Deformed wing virus), vectored by $V$. destructor, are related to winter mortality [54]. In Southern England, a 1-year-long survey of colonies treated against Varroa mites has reported multiple virus infectionsDWV, ABPV and BQCV (Black queen cell virus), with a significant correlation observed between DWV infestation and overwinter colony losses [55]. Another survey in Poland has revealed severe to moderate winter colony losses related to co-infection with $\mathrm{DWV}, \mathrm{ABPV}$, BQCV, CBPV (Chronic bee paralysis virus) and SBV (Sacbrood virus), V. destructor and $N$. ceranae infestation [56]. Increased overwinter mortality has been observed in Belgium, the main reason for this being the co-infection with ABPV and CBPV, transmitted by $V$. destructor and SBV, taking into account that ABPV had a significant and profound effect [34]. 
There are many more examples in this regard, but it is obvious that honey beeassociated viruses are a serious problem for winter bee mortality in many parts of the world. The results of the conducted researches indicate the role of the Varroa mite as a transmitter of a large number of honey bee-associated viruses, its resistance to certain acaricides, the negative impact of pesticides, etc.

Another point of view is that high winter colony losses occur as a result of the synergistic effect of different pathogens which act simultaneously in co-infection, thus aggravating the pathological picture-e.g., $V$. destructor and honey bee associated viruses, $N$. ceranae and viruses $[57,58]$, individual pathogens and pesticides, e.g., $N$. ceranae and neonicotinoids [59,60], $V$. destructor and neonicotinoids [61,62], honey bee associated viruses and neonicotinoids [63,64], or combinations of pesticides, e.g., insecticides and fungicides $[65,66]$.

\subsection{Effects from the Application of Herbal Supplements on Biochemical and Immunological Parameters in Honey Bee Haemolymph}

Biochemical and immunological parameters in bee haemolymph are very important with regard to the strength of honey bee colonies, honey bee health, and protection against various diseases. Therefore, many contemporary researchers focus on studying how the application of different natural products affects these parameters. For example, the administration of the commercial probiotic $\mathrm{EM}^{\circledR}$ PROBIOTIC FOR BEES (5\%), applied as sugar syrup, has been found to increase the total protein content and the vitellogenin concentration in honey bee haemolymph [67]. Another study has shown that the application of piperine [(E,E)-5-(3,4-Methylenedioxyphenyl)-2,4-pentadienoylpiperidide, 1-Piperoylpiperidine] $(3 \mu \mathrm{g} / \mathrm{mL})$ dissolved in sugar syrup at a ratio of 1:1 can increase the antioxidative activity of enzymes such as superoxide dismutase (SOD), glutathione peroxidase (GPx), catalase (CAT), and glutathione S-transferase (GST) [68]. The authors have concluded that the natural supplement pepirine improved the health status of honey bees and increased their resistance against various stress factors. Similar results have been obtained after administration of an artificial diet including a pollen substitute, applied as a cake, supplemented with vitamin C [69]. The authors observed higher activities of SOD and catalase CAT as well as higher levels of glutathione (GSH) and lipid peroxidation (LPO) in bee colonies fed with this supplemental diet. On the basis of the obtained results, they have suggested that the supplemental winter feeding can significantly improve colony development and health during overwintering.

This research has clearly demonstrated that different herbal supplements applied at the end of autumn represent a reliable strategy for increasing the activity of antioxidant enzymes and the concentration of total protein and vitellogenin in honey bee haemolymph, which is a prerequisite for successful overwintering and reduction of overwintering honey bee losses.

The fact that the majority of colony losses occur during winter motivated us to conduct the present study. Here, we have examined the impact of the application of two herbal products, NOZEMAT HERB ${ }^{\circledR}(\mathrm{NH})$ and NOZEMAT HERB PLUS ${ }^{\circledR}(\mathrm{NHP})$, on honey bee colonies' survival in the winter. As the immunity of the honey bee depends largely on the protein and lysozyme content in the bee haemolymph, we decided to investigate them as proper biochemical markers for the activity of the humoral part of the immune system after application of the herbal extracts.

\section{Materials and Methods}

All experimental procedures were reviewed and approved by the Animal Research Ethics Committee of the Bulgarian Food Safety Agency (BFSA), (Ar. 154 from of the Law on Veterinary Activity) in accordance with the European Union Directive 86/609. 


\subsection{Experimental Design}

The study was conducted in two consecutive years (2019 and 2020) at the Experimental Apiary of the Research Center of Stockbreeding and Agriculture-Smolyan, Bulgaria $\left(41^{\circ} 35^{\prime} 7.01^{\prime \prime} \mathrm{N} 24^{\circ} 41^{\prime} 30.98^{\prime \prime} \mathrm{E}\right)$.

In this research we used two herbal extracts, NOZEMAT HERB ${ }^{\circledR}(\mathrm{NH})$ and NOZEMAT HERB PLUS ${ }^{\circledR}$ (NHP), produced by Extract Pharma Ltd., Sofia, Bulgaria. These products are patented herbal supplements for honey bees. NH contains herbal extracts (flavonoids, polyphenols, polysaccharides, mucous substances, amino acids, essential oils, vitamins, minerals etc.), pure vegetable glycerin, water, citric acid, and preservative-potassium sorbate. NHP contains additional herbal extract as well as vitamin C (ascorbic acid). The exact quantitative composition of these two supplements is patent-protected (registration No. 012778118), therefore it has not been disclosed in this paper.

To study the influence of these two supplements on honey bee winter survival, 45 colonies were randomly selected and divided into three treatment groups- $\mathrm{NH}(n=15)$, $\operatorname{NHP}(n=15)$ and C $(n=15)$.

All hives had exposure to the same environment and the same forage conditions. The bee colonies were equalized in terms of bee colony strength, queen bee age, sealed worker brood area, amount of honey and stored pollen area. To prevent the impact of $V$. destructor during the winter, all groups were treated twice every 14 days in August 2019 with Furmitom ${ }^{\circledR}$ ("EVROTOM" LLC, Serbia). Before wintering, when there was no longer sealed brood, the treatment against varroasis was performed with oxalic acid. The solution for the treatment was prepared as follows: $30 \mathrm{~g}$ oxalic acid and $100 \mathrm{~g}$ sugar were dissolved in $1 \mathrm{~L}$ water. Each frame with bees in the hive was sprayed with $5 \mathrm{~mL}$ of the prepared solution.

The treatment of the bee colonies with herbal supplements was carried out in the autumn (5 August 2019). The bee colonies from the NH and NHP groups were treated four times at 7-day intervals with the two supplements at a dose of $10 \mathrm{~mL}$ of the product dissolved in $100 \mathrm{~mL}$ of sugar syrup $(1: 1, \mathrm{w} / \mathrm{w})$, according to the manufacturer's instructions (Extract Pharma Ltd., Sofia, Bulgaria). The solution was sprayed with a syringe onto the bee combs in each experimental hive. The colonies in Group $C$ served as a control group and were sprayed only with sugar syrup $(1: 1, w / w)$, at the same dose as the experimental groups.

In 2020, during the active period of development of the bee colonies (FebruaryOctober), we performed two feedings (9 April and 3 August) with NH and NHP in order to evaluate the amount of total protein and lysozyme in the haemolymph of young worker bees.

\subsection{Evaluation of Food Consumption and Bee Mortality}

The following two parameters were analyzed during the first clinical examination of honey bee colonies in the spring of the following year (March 2020).

(1) The amount of food consumption from the bee colony during the winter-this parameter was evaluated based on the difference between the amount of honey during wintering and the amount of honey in the first clinical examination of honey bee colonies, following standard norms (Conditions and procedure for performance of selection and reproduction activities in beekeeping ORDINANCE No. 35, 2004, issued by The Bulgarian Ministry of Agriculture, Food and Forestry, https:/ /www. mzh.government.bg/en/, accessed on 15 May 2021) (Table 1). The amount of the consumed food was added to the amount of the honey-sugar paste which bees used in the winter. Food consumption per unit of bees was evaluated according to the following formula:

$$
\mathrm{M}=\mathrm{C} / 0.5 \times(\mathrm{A}+\mathrm{B})
$$

where $\mathrm{M}$ denoted the consumed food per unit of bees (frames, number, $\mathrm{kg}$ ) in winter; $\mathrm{C}$ - the total amount of consumed food $(\mathrm{kg})$; A — the strength of the bee colony in the 
autumn (frames, number, $\mathrm{kg}$ ); and B - the strength of the bee colony in the spring (frames, number, kg).

Table 1. Assessment of honey bee colony food consumption in the winter.

\begin{tabular}{ccc}
\hline Rank & Food Consumption from One Frame with Bees $\mathbf{( K g )}$ & Assessment of the Parameter \\
\hline 5 & $0.6-1.0$ & Very good wintering \\
4 & $1.1-1.4$ & Good wintering \\
3 & $1.5-1.8$ & Satisfactory wintering \\
2 & $1.9-2.2$ & Bad wintering \\
1 & Over 2.3 & Very bad wintering \\
\hline
\end{tabular}

The strength of the bee colony was estimated based on its mass $(\mathrm{kg})$, which was calculated according to the method described by Delaplane et al. [70].

The amount of honey in the beehives was calculated as proposed by Delaplane et al. [71]

(2) Bee mortality (winter colony losses \%)-the difference between the strength of the bee colony in the autumn and in the spring (Conditions and procedure for performance of selection and reproduction activities in beekeeping ORDINANCE No. 35, 2004, issued by The Bulgarian Ministry of Agriculture, Food and Forestry (https:/ / www. mzh.government.bg/en/, accessed on 15 May 2021) (Table 2). This parameter was evaluated according to the following formula:

$$
\mathrm{P}=(\mathrm{A}-\mathrm{B}) / \mathrm{A} \times 100
$$

where P denoted the amount of dead bees (winter colony losses, \%); A-the strength of the bee colony in the autumn; and B-the strength of the bee colony in the spring.

Table 2. Assessment of winter honey bee colony losses.

\begin{tabular}{ccc}
\hline Rank & Quantity of Fead Bees (\%) & Assessment of the Parameter \\
\hline 5 & Under 15 & Very good wintering \\
4 & $15-19.99$ & Good wintering \\
3 & $20-29.99$ & Satisfactory wintering \\
2 & $30-49.99$ & Bad wintering \\
1 & Over 50 & Very bad wintering \\
\hline
\end{tabular}

\subsection{Evaluation of Total Protein and Lysozyme Content in the Bee Haemolymph}

The haemolymph was collected from newly emerged bees approximately two months after the application of NH and NHP (June 2020 and September 2020). The haemolymph was obtained from all experimental groups according to the new antennae method for haemolymph sampling described by Borsuk et al. [71].

The total protein concentration in the haemolymph was determined spectrophotometrically (UV-Vis spectrophotometer, PG Instruments Limited, Leicestershire, United Kingdom) at $530 \mathrm{~nm}$ [72].

The lysozyme levels in the haemolymph were determined by a Lysozyme Detection Kit (Cat. No, LY0100, Sigma-Aldrich Co. LLC, St. Louis, MO, USA), according to the manufacturer's instructions. In this analysis, the lysozyme activity results in the lysis of the Micrococcus lysodeikticus cells. During incubation of the lysozyme sample and substrate, the reaction is followed by monitoring the decrease in absorbance at $450 \mathrm{~nm}$ [73].

\subsection{Statistical Analysis}

The dependent variables studied and normalized by linear transformation were: strength (mass) of honey bee colonies, amount of honey, and total protein and lysozyme levels in the haemolymph. These variables in the investigated groups were compared using F-statistic, a one-way ANOVA analysis of variance (IBM SPSS Statistics 23.0 for 
Windows) with a post hoc Tukey HSD test for multiple comparisons using pairwise $t$-tests with Bonferroni adjustments.

\section{Results}

3.1. Effect of the Herbal Supplements NH and NHP on Overwitering Food Consumption and Bee Mortality

\subsubsection{Overwintering Food Consumption}

The amount of food consumption from the bee colonies during the winter is presented in Table 3. The values of this parameter were assessed according to the Conditions and procedure for performance of selection and reproduction activities in beekeeping ORDINANCE No. 35, 2004, issued by The Bulgarian Ministry of Agriculture, Food and Forestry (https:/ / www.mzh.government.bg/en/, accessed on 15 May 2021) (Table 1). The quantity of honey in the first clinical examination of honey bee colonies in $\mathrm{NH}(3.42 \pm 0.27 \mathrm{~kg})$ and NHP $(3.24 \pm 0.14 \mathrm{~kg})$ groups was significantly higher, compared to the control C group $(0.48 \pm 0.27 \mathrm{~kg})(F=37.153, d f=18, p=0.001, p<0.01 ; F=33.841, d f=18, p=0.001$, $p<0.01$, respectively). These results indicate that the application of both herbal supplements significantly reduces the amount of food consumed in winter. Bee colonies fed with $\mathrm{NH}$ consumed significantly less food overwintering than those fed with $\mathrm{NHP}(F=5.469$, $d f=28, p=0.026, p<0.05)$. The indicator of total amount of consumed food shows a similar dependence between the control and the NH and NHP groups. The bee colonies from the control C group $(9.67 \pm 0.19 \mathrm{~kg})$ consumed significantly more food, approximately $30 \%$ and $20 \%$ more, compared to the NH $(6.76 \pm 0.30 \mathrm{~kg})$ and the NHP group $(7.07 \pm 0.14 \mathrm{~kg})$ $(F=36.339, d f=23, p=0.001, p<0.01 ; F=38.615, d f=23, p=0.001, p<0.01$, respectively $)$. In addition, there was a significant difference in the total amount of food consumed in bee colonies treated with NH compared to those treated with NHP $(F=13.382, d f=18$, $p=0.001, p<0.01)$. Finally, the calculated consumed food per one frame of bees in the $\mathrm{NH}$ $(1.29 \pm 0.01 \mathrm{~kg})$ and the NHP group $(1.38 \pm 0.09 \mathrm{~kg})$ was significantly less than that in the control C group $(2.08 \pm 0.19 \mathrm{~kg})(F=23.396, d f=18, p=0.001, p<0.01 ; F=17.688, d f=18$, $p=0.001, p<0.01$, respectively). The bee colonies treated with $\mathrm{NH}$ consumed about $7 \%$ less food than those treated with NHP $(F=13.741, d f=18, p=0.009, p<0.01)$. The obtained results regarding the parameter of consumed food per one frame of bees in the $\mathrm{NH}$ and NHP groups indicate good wintering in these bee colonies, according to the classification proposed by the Conditions and procedure for performance of selection and reproduction activities in beekeeping ORDINANCE No. 35, 2004, issued by The Bulgarianm Ministry of Agriculture, Food and Forestry (https: / / www.mzh.government.bg/en/, accessed on 15 May 2021) (Table 1). The value of this parameter in the control C group $(2.08 \pm 0.19 \mathrm{~kg})$ indicates bad wintering in these bee colonies. Our results show that the use of either herbal supplement is associated with much lower food consumption in overwintering bee colonies, and the use of NH is more appropriate than the application of NHP.

Table 3. Overwintering food consumption from the bee colonies.

\begin{tabular}{|c|c|c|c|c|c|}
\hline Groups & $\begin{array}{c}\text { Quantity of Honey } \\
\text { in Autumn Review } \\
\text { (kg) }\end{array}$ & $\begin{array}{c}\text { Amount of Honey-Sugar } \\
\text { Paste Given in the } \\
\text { Winter (kg) }\end{array}$ & $\begin{array}{c}\text { Quantity of Honey } \\
\text { in Spring Review } \\
(\mathrm{kg})\end{array}$ & $\begin{array}{c}\text { Total Amount of } \\
\text { Consumed Food } \\
(\mathbf{k g})\end{array}$ & $\begin{array}{c}\text { Consumed Food per } \\
\text { One Frame of Bees } \\
(\mathbf{k g})\end{array}$ \\
\hline Control (C) & $7.14 \pm 0.13^{a}$ & 3.0 & $0.48 \pm 0.27^{\mathrm{a}}$ & $9.67 \pm 0.19^{a}$ & $2.08 \pm 0.19^{a}$ \\
\hline $\begin{array}{c}\text { NOZEMAT } \\
\text { HERB }^{\circledR}\end{array}$ & $7.18 \pm 0.05^{a}$ & 3.0 & $3.42 \pm 0.27^{\mathrm{b}}$ & $6.76 \pm 0.30^{b}$ & $1.29 \pm 0.01^{b}$ \\
\hline $\begin{array}{c}\text { NOZEMAT HERB } \\
\text { PLUS }^{\circledR}\end{array}$ & $7.31 \pm 0.08^{a}$ & 3.0 & $3.24 \pm 0.14^{b}$ & $7.07 \pm 0.14^{b}$ & $1.38 \pm 0.09^{b}$ \\
\hline
\end{tabular}

Data represent mean value \pm standard deviation. Values within the column that are denoted with similar superscript letters ("a" or " $b$ ") are not significantly different according to Tukey's post hoc multiple comparison test.

\subsubsection{Overwintering Colony Losses}

The results from our study of the impact of the application of NOZEMAT HERB ${ }^{\circledR}$ and NOZEMAT HERB PLUS ${ }^{\circledR}$ on bee mortality are presented in Figure 1. The honey bee 
colony losses were evaluated according to the Conditions and procedure for performance of selection and reproduction activities in beekeeping ORDINANCE No. 35, 2004, issued by The Bulgarian Ministry of Agriculture, Food and Forestry (https: / /www.mzh.government. $\mathrm{bg} / \mathrm{en} /$, accessed on 15 May 2021) (Table 2). The control C group showed very significant differences when compared to the NH and NHP groups. The percent of very bad wintering of honey bee colonies $(40 \%)$ was rather high and observed only in the control group. The percent of good wintering of honey bee colonies was the highest in the NHP group (53\%), compared to the control C $(20 \%)$ and the $\mathrm{NH}(44 \%)$ group. The highest percentage of very good wintering bee colonies was observed in the $\mathrm{NH}$ group (56\%). Surprisingly, the bad wintering colonies in the NHP group $(27 \%)$ were slightly higher than those in the control group (20\%). There were no bad wintering colonies in the NH group (Figure 1). The obtained results give us a reason to conclude that $\mathrm{NH}$ has a positive effect on the successful overwintering of bee colonies. Unlike NH, the other herbal supplement, NHP, has shown a lower effect on the overwintering honey bee colonies, as the obtained results in terms of bad and very good wintering bee colonies in this group are similar to those in the control C group (Figure 1).
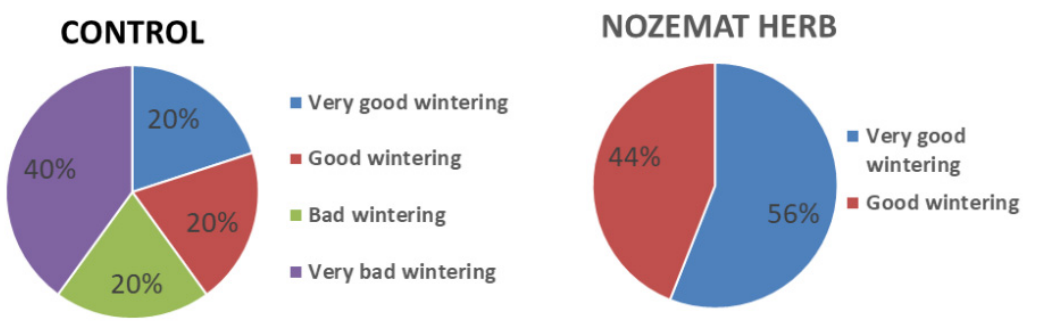

NOZEMAT HERB PLUS

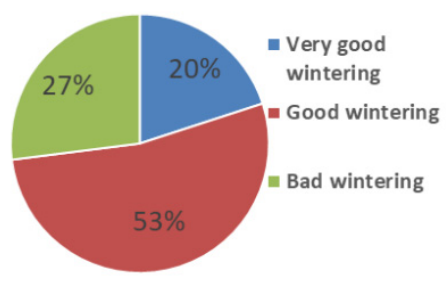

Figure 1. Honey colony overwintering (\%) after application of herbal supplements NOZEMAT HERB $^{\circledR}$ and NOZEMAT HERB PLUS ${ }^{\circledR}$.

3.2. Effect of Herbal Supplements on Total Protein and Lysozyme Content in the Bee Haemolymph 3.2.1. Influence of the Herbal Supplements NH and NHP on the Total Protein Content in the Bee Haemolymph

The protein content in the bee haemolymph was evaluated approximately two months after the application of NOZEMAT HERB ${ }^{\circledR}$ and NOZEMAT HERB PLUS ${ }^{\circledR}$ in June 2020 and in September 2020 (Figure 2). The obtained results of the values of this parameter in June 2020 showed higher protein content in the NH group $(77.25 \pm 8.79 \mathrm{~g} / \mathrm{L})$ and the NHP group $(73.10 \pm 10.55 \mathrm{~g} / \mathrm{L})$, compared to the control C group $(62.17 \pm 6.28 \mathrm{~g} / \mathrm{L})(F=6.285, d f=6$, $p=0.054 ; F=1.274, d f=6, p=0.310$, respectively), but the differences were not statistically significant. During the second investigation (September 2020), a decrease in the values of this indicator was observed more than twice in all three experimental groups. Then, the protein content remained the highest in the NH group $(35.34 \pm 11.05 \mathrm{~g} / \mathrm{L})$, compared to the NHP $(30.88 \pm 13.01 \mathrm{~g} / \mathrm{L})$ and the control C $(31.41 \pm 13.79 \mathrm{~g} / \mathrm{L})$ group $(F=0.097$, $d f=6, p=0.785 ; F=0.073, d f=6, p=0.803$, respectively). Similar to the study in June 2020, in September 2020 no significant differences were found between the three experimental groups with regard to protein content in the bee haemolymph. Notable differences in relation to this indicator were established when comparing the results from June with those obtained in September. In the autumn the protein content in the NH group decreased 
significantly more, by over $50 \%$ (from $77.25 \pm 8.79 \mathrm{~g} / \mathrm{L}$ to $35.34 \pm 11.05 \mathrm{~g} / \mathrm{L}$ ) (ANOVA with Tukey's HSD post hoc test $F=26.502, d f=6, p=0.006, p<0.01$ ). Compared to July $2020(73.10 \pm 10.55 \mathrm{~g} / \mathrm{L})$, the protein content of NHP group decreased significantly more, by $58 \%$ in September 2020 (30.88 $\pm 13.01 \mathrm{~g} / \mathrm{L}$ ) (ANOVA with Tukey's HSD post hoc test $F=9.373, d f=6, p=0.037, p<0.05)$, while in the control $C$ group the decrease was about $50 \%$ (ANOVA with Tukey's HSD post hoc test $F=7.968, d f=6, p=0.048, p<0.05$ ).

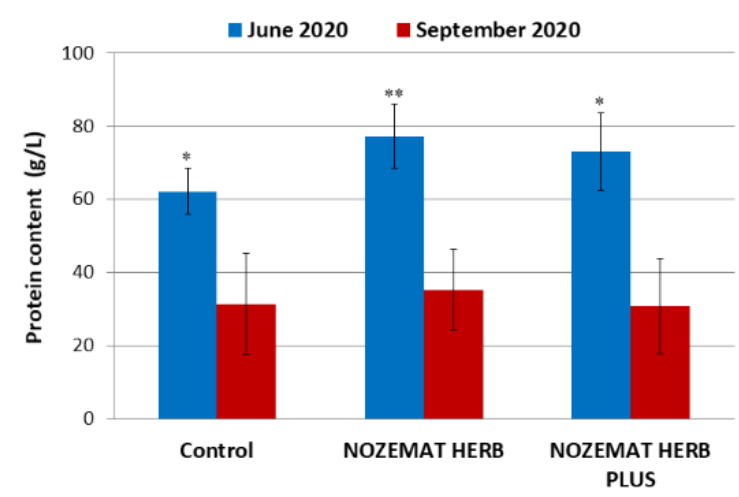

Figure 2. Average $( \pm S D)$ values of total protein content $(\mathrm{g} / \mathrm{L})$ in the bee haemolymph after application of herbal supplements NOZEMAT HERB ${ }^{\circledR}$ and NOZEMAT HERB PLUS ${ }^{\circledR}$ and in an untreated (control) group. Asterisks indicate the level of significance as determined by an analysis of variance followed by Tukey's post hoc multiple comparison test. ${ }^{*} p<0.05,{ }^{* *} p<0.01$.

The results of the study have shown that only NOZEMAT HERB ${ }^{\circledR}$ significantly affects levels of protein content (Figure 2).

3.2.2. Influence of the Herbal Supplements NH and NHP on Lysozyme Content in the Bee Haemolymph

Analogously to the assessment of the total protein content in the bee haemolymph, the lysozyme content was assessed approximately two months after the application of NOZEMAT HERB $^{\circledR}$ and NOZEMAT HERB PLUS ${ }^{\circledR}$ (June 2020 and September 2020) (Figure 3). In June 2020, the NHP group $(0.56 \pm 0.23 \mathrm{mg} / \mathrm{L})$ showed significantly higher values of this parameter compared to the control C group $(0.20 \pm 0.7 \mathrm{mg} / \mathrm{L})$ and the $\mathrm{NH}$ group $(0.09 \pm 0.3 \mathrm{mg} / \mathrm{L})(F=6.415, d f=6, p=0.044, p<0.05 ; F=15.938, d f=6, p=0.005$, $p<0.01$, respectively). The obtained results from the first application of the herbal supplements show a significant effect of NHP on the lysozyme content in the bee haemolymph compared to $\mathrm{NH}$. It is interesting to note that during the second investigation (September $2020)$ the value of the lysozyme content in the NH group $(0.18 \pm 0.8 \mathrm{mg} / \mathrm{L})$ increased twofold compared to the previous measurement $(F=4.401, d f=6, p=0.090)$; however, the differences were not statistically significant. A slight increase was also observed in the control C group $(0.25 \pm 0.5 \mathrm{mg} / \mathrm{L})(F=0.924, d f=6, p=0.390)$, while the lysozyme content decreased in the NHP group $(0.47 \pm 0.11 \mathrm{mg} / \mathrm{L})(F=0.243, d f=6, p=0.642)$. Despite an observed decrease in the lysozyme content in September 2020 compared to its first administration in June 2020, the lysozyme values in the NHP group in the autumn maintained higher levels compared to the $\mathrm{NH}$ and the control $\mathrm{C}$ groups $(F=11.172, d f=6$, $p=0.044, p<0.05 ; F=9.902, d f=6, p=0.051$, respectively).

The obtained results from the administration of the two herbal supplements clearly demonstrate a positive effect of NOZEMAT HERB ${ }^{\circledR}$ application on the lysozyme content in honey bee haemolymph (Figure 3). 


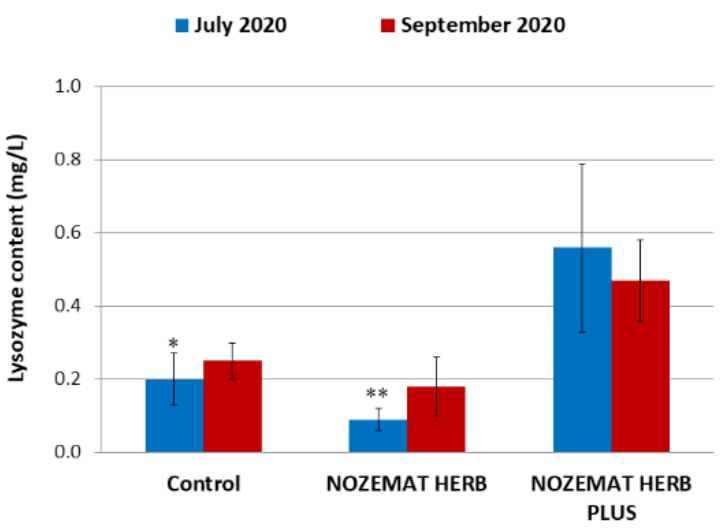

Figure 3. Average $( \pm \mathrm{SD})$ values of lysozyme content $(\mathrm{mg} / \mathrm{L})$ in the bee haemolymph after application of herbal supplements NOZEMAT HERB ${ }^{\circledR}$ and NOZEMAT HERB PLUS ${ }^{\circledR}$ and in an untreated (control) group. Asterisks indicate the level of significance as determined by an analysis of variance followed by Tukey's post hoc multiple comparison test. ${ }^{*} p<0.05,{ }^{* *} p<0.01$ compared to the untreated control and $\mathrm{NH}$ group.

\section{Discussion}

Winter honey bee colony losses pose a serious challenge to modern beekeeping. It is difficult to distinguish the most significant cause of this negative phenomenon, as many different factors are usually involved, often acting simultaneously.

In this work we have traced the in vivo effect of two plant supplements NOZEMAT HERB $^{\circledR}(\mathrm{NH})$ and NOZEMAT HERB PLUS ${ }^{\circledR}$ (NHP) on honey bee colony overwintering. Our previous experience had shown that both herbal supplements can be successfully used as an alternative therapy against $N$. ceranae infection, and can increase the bee colony strength, the amount of capped honey and bee collected pollen [74]. The obtained results in the present study have clearly demonstrated the positive effect from the application of $\mathrm{NH}$ and NHP on overwintering honey bee colony survival, and in this respect $\mathrm{NH}$ appears to be more efficient (Figure 1). We have found that after the application of the two herbal supplements the percentage of good wintering bee colonies was $53 \%$ in the $\mathrm{NHP}$ and $43 \%$ in the NH group, while in the control C group it was only $20 \%$. Moreover, we have observed an extremely high percentage of very good wintering bee colonies in the $\mathrm{NH}$ group (56\%), as after the application of the two herbal supplements no bee losses were found.

Since plant extracts are not antibiotics and are usually not toxic to humans and animals, in recent years they have been widely used in beekeeping, thus avoiding the accumulation of harmful residues in bee products. Thus, for example, the application of seaweed extract (HiveAlive ${ }^{\mathrm{TM}}$ ) before and after the winter has been found to have a positive effect on honey bee health and population increase during the spring [75]. Another study has revealed that the application of chamomile (Matricaria chamomilla), added to sugar feeding, enhances the survival of honey bee colonies [76]. The application of 75\% ethanol Eleutherococcus senticosus root extract in a concentration of $0.4 \mathrm{mg} / \mathrm{mL}$ in sucrose solution in late summer significantly increases honey bee winter survival [77]. It has been shown that the major antioxidant in green tea (Camellia sinensis) - epigallocatechin-3-gallate (EGCG, natural antioxidant) has a positive effect on honey bee survival [78]. A three-year field experiment has demonstrated the beneficial effect of the application of the medicinal mushroom Agaricus brasiliensis extract, which helps to maintain strong colonies when overwintering [79]. Many more examples can be given about the positive effect of plant extracts on overwintering honey bee colony health and survival, but the main question that arises is: what are the active substances in these plants that mediate a positive effect on bee colonies?

Although our experiments were not designed to determine the mechanism(s) behind the positive effects of NH and NHP, we have tried to reach and provide some explanation. Since both herbal supplements contain mainly flavonoids and polyphenols, we 
presume that these secondary plant metabolites help for the successful overwintering of bee colonies. Medicinal plants have long been reported as a valuable source of natural antioxidant compounds, particularly plant secondary metabolites, i.e., phenolic compounds and flavonoids, which are generated by plants to defend themselves or to promote growth under unfavorable conditions [80-82]. Phenolics and flavonoids are commonly known as the largest phytochemical molecules with antioxidant properties from plants, which may prevent the degenerative effect (oxidative stress) from unbalanced concentration of reactive oxygen species (ROS) and reactive nitrogen species (RNS) [83-85]. Different researchers have confirmed the antibacterial activity of plant-derived compounds such as flavonoids, hydroxycinnamic, and phenolcarboxylic acids and their esters [86-88]. Finally, there is strong evidence that some phenolic compounds ( $p$-coumaric acid) upregulate both detoxification genes and immunity genes. Bees consuming $p$-coumaric acid within their diet were capable of $60 \%$ higher rates of metabolism of the organophosphate acaricide [89]. Moreover, it has been observed that multiple flavonoids and phenolic acids upregulate the P450 genes encoding key detoxification enzymes in adults honey bees, including CYP9Q1, CYP9Q2, and CYP9Q3, which detoxify a number of insecticides (tau-fluvalinate, coumaphos, $\beta$-cyfluthrin, bifenthrin etc. [90-92].

With regard to total protein content in honey bee haemolymph, we found that about two months after the first application of NH and NHP there were higher values of this parameter in the NH $(73.10 \pm 10.55 \mathrm{~g} / \mathrm{L})$ and the NHP $(77.25 \pm 8.79 \mathrm{~g} / \mathrm{L})$, compared to the control $C$ group $(62.17 \pm 6.28 \mathrm{~g} / \mathrm{L})$, while after the second administration of two herbal supplements, there was no difference among the three experimental groups (Figure 2). The content of lysozyme in the bee haemolymph was most strongly affected after the application of NHP (Figure 3).

It has been suggested that total protein and lysozyme content in bee haemolymph are closely related to the hygienic behavior in honey bee, i.e., hygienic bee colonies have higher lysozyme content and lower total protein content vs nonhygienic bee colonies [93]. Hygienic behavior is a very important physiological mechanism of honeybee workers to prevent the spreading of various pathogens over the honeybee brood [94].

There is direct evidence that the total concentration of proteins, the level of vitellogenin, and the antibacterial activity of haemolymph are different in the so-called "summer bees" and "winter bees" $[95,96]$. The longevity of "winter bees" is very important for honey bee winter survival, because these bees regulate colony temperature and initiate brood rearing at the winter's end, when this generation is replaced by a new summer generation [97]. One of the biochemical markers associated with longevity in "winter bees" is the content of proteins in the haemolymph, i.e., these bees have higher protein content compared to "summer bees" [96]. As the functions of the cellular part of the immune system in long-living bees are limited, honey bees have to rely on the humoral part of the immune system during the winter period. This is associated with higher expression of antimicrobial genes, such as apidaecin, hymenoptaecin, and abaecin, or antibacterial compounds, such as lysozyme content in haemolymph $[98,99]$. Moreover, this increase in antibacterial activity correlates with higher protein levels in honey bee haemolymph in the winter. Regarding cellular immunity, it has been suggested that haemocyte (involved in the phagocytosis and encapsulation of parasites) concentration is associated with diet diversity [100]. According to these authors, considering that the nitrogen content was equal in mono- and polyfloral diets, additional minor components such as vitamins, phenolic compounds, and flavonoids, as well as essential amino acids in mixed pollen might be the main reason for enhanced cellular immunity.

Besides the antioxidant capacity of the phenolic compounds (phenolic acids and flavonoids), the antioxidant activity of water-soluble vitamins such as vitamin C (L-ascorbic acid) is also well known [101]. Vitamin C acts as a reducing agent, capable of rapidly scavenging a number of ROS and RSN species and providing an important antioxidant protection [102]. Therefore, the effect of supplementing honey bee diet with vitamin $C$ (ascorbic acid) during overwintering has been studied as well [103]. It has been observed 
that feeding of honey bee colonies with water syrup (3:1) supplemented with vitamin C in the beginning of September is associated with lower winter mortality of bees, higher contents of protein, total antioxidant status (TAS), glutathione, and antioxidative enzyme (peroxidase, catalase, and glutathione transferase) activity in worker bees emerging in spring. These results suggest that vitamin $\mathrm{C}$ can be recommended as a natural, safe, and relatively cheap diet supplement, elevating the resistance to stress factors (including diseases in which oxidative stress plays a key role) affecting wintering bees and spring generations of worker bees [103].

These data provide grounds for explanation of the obtained results from our investigation. Indeed, the only difference in the composition of NH and NHP is the presence of vitamin $C$ in the latter. This fact, as well as the observed higher content of total protein and lysozyme in the haemolymph of bees in the late autumn, gives us reason to expect higher longevity and survival in winter from bee colonies in the NHP group, considering their humoral immunity, and lysozyme content, in particular (Figure 3), as well as their increased antioxidant defense capacity due to the additional inclusion of vitamin $\mathrm{C}$. These assumptions are further supported by the established high percentage of good wintering honey bee colonies (Figure 1). Moreover, we suggest that the levels of total protein and lysozyme content in honey bee haemolymph in the late autumn may be used as markers of long-living honey bee populations.

\section{Conclusions}

In conclusion, this has been the first study in Bulgaria to evaluate in vivo the effects of the herbal supplements NOZEMAT HERB ${ }^{\circledR}$ and NOZEMAT HERB PLUS ${ }^{\circledR}$ on overwintering honey bee colony survival and on total protein and lysozyme content in bee haemolymph. The results of this study have shown that the administration of the two herbal supplements has a positive impact on overwintering honey bee colonies, whereby NOZEMAT HERB ${ }^{\circledR}$ has a more pronounced effect. We have also shown that the application of NOZEMAT HERB PLUS ${ }^{\circledR}$ is associated with a higher level of total protein and lysozyme content in honey bee haemolymph, which determines higher longevity in "winter bees", due to the higher activity of the humoral immune system and the higher antioxidant capacity (enhanced by the presence of vitamin C).

Future studies are needed to confirm these results and also to test different doses of NOZEMAT HERB ${ }^{\circledR}$ and NOZEMAT HERB PLUS ${ }^{\circledR}$ so as to elucidate and optimize the mechanism of action of these herbal supplements. Additionally, long-term studies are necessary to determine that the treatments have no adverse effects on honey bee health, colony development, and productivity. However, our findings on the application of these two supplements provide a reasonable basis for further research and development of a potentially efficient measure to decrease overwintering honey bee losses.

Author Contributions: Conceptualization, R.S. and R.B.; methodology, R.S., R.B., P.H. and T.K.; investigation, R.S. and R.B.; data curation, R.S., R.B. and P.H.; writing-original draft preparation, R.S., R.B. and P.H.; writing-review and editing, R.S., R.B., P.H. and T.K. All authors have read and agreed to the published version of the manuscript.

Funding: This research was funded by the NATIONAL SCIENTIFIC FUND OF THE BULGARIAN MINISTRY OF EDUCATION AND SCIENCE, grant number 06/10 17.12.2016. The APC was funded by grant number 06/10 17 December 2016.

Institutional Review Board Statement: The study was conducted according to the guidelines of the Declaration of Helsinki, and approved by the Ethics Committee of the RESEARCH CENTRE OF STOCKBREEDING AND AGRICULTURE, Smolyan, Bulgaria (protocol code 627/30.03.2015).

Data Availability Statement: The data presented in this study are available on request from the corresponding author.

Acknowledgments: The authors wish to thank the anonymous reviewers for their constructive comments on the manuscript. We thank Ilian Gechev for kindly providing both herbal supplements. We also thank Maya Marinova (IBPhBME-BAS, Bulgaria) for the English editing. 
Conflicts of Interest: The authors declare no conflict of interest. The funders had no role in the design of the study; in the collection, analyses, or interpretation of data; in the writing of the manuscript, or in the decision to publish the results.

\section{References}

1. Ballantyne, G.; Baldock, K.C.R.; Rendell, L.; Willmer, P.G. Pollinator Importance Networks Illustrate the Crucial Value of Bees in a Highly Speciose Plant Community. Sci. Rep. 2017, 7, 8389. [CrossRef]

2. Li, Q.-Q.; Wang, K.; Marcucci, M.C.; Sawaya, A.C.H.F.; Hu, L.; Xue, X.-F.; Wu, L.-M.; Hu, F.-L. Nutrient-Rich Bee Pollen: A Treasure Trove of Active Natural Metabolites. J. Funct. Foods 2018, 49, 472-484. [CrossRef]

3. El-Seedi, H.R.; Khalifa, S.A.M.; El-Wahed, A.A.; Gao, R.; Guo, Z.; Tahir, H.E.; Zhao, C.; Du, M.; Farag, M.A.; Musharraf, S.G.; et al. Honeybee Products: An Updated Review of Neurological Actions. Trends Food Sci. Technol. 2020, 101, 17-27. [CrossRef]

4. Gray, A.; Adjlane, N.; Arab, A.; Ballis, A.; Brusbardis, V.; Charrière, J.D.; Chlebo, R.; Coffey, M.F.; Cornelissen, B.; da Costa, C.A.; et al. Honey bee colony winter loss rates for 35 countries participating in the COLOSS survey for winter 2018-2019, and the effects of a new queen on the risk of colony winter loss. J. Apic. Res. 2020, 59, 744-751. [CrossRef]

5. Amiri, E.; Strand, M.K.; Rueppell, O.; Tarpy, D.R. Queen quality and the impact of honey bee diseases on queen health: Potential for interactions between two major threats to colony health. Insects 2017, 8, 48. [CrossRef]

6. Steinhauer, N.; Kulhanek, K.; Antúnez, K.; Human, H.; Chantawannakul, P.; Chauzat, M.P.; vanEngelsdorp, D. Drivers of colony losses. Curr. Opin. Insect Sci. 2018, 26, 142-148. [CrossRef]

7. vanEngelsdorp, D.; Tarpy, D.R.; Lengerich, E.J.; Pettis, J.S. Idiopathic brood disease syndrome and queen events as precursors of colony mortality in migratory beekeeping operations in the eastern United States. Prev. Vet. Med. 2013, 108, 225-233. [CrossRef]

8. Giacobino, A.; Molineri, A.; Cagnolo, N.B.; Merke, J.; Orellano, E.; Bertozzi, E.; Masciangelo, G.; Pietronave, H.; Pacini, A.; Salto, C.; et al. Queen Replacement: The Key to Prevent Winter Colony Losses in Argentina. J. Apic. Res. 2016, 55, 335-341. [CrossRef]

9. Zee, R.V.D.; Brodschneider, R.; Brusbardis, V.; Charriere, J.D.; Chlebo, R.; Coffey, M.F.; Dahle, B.; Drazic, M.M.; Kauko, L.; Kretavicius, J.; et al. Results of international standardised beekeeper surveys of colony losses for winter 2012-2013: Analysis of winter loss rates and mixed effects modelling of risk factors for winter loss. J. Apic. Res. 2014, 53, 19-34. [CrossRef]

10. Oberreiter, H.; Brodschneider, R. Austrian COLOSS survey of honey bee colony winter losses 2018/19 and analysis of hive management practices. Diversity 2020, 12, 99. [CrossRef]

11. Brown, P.; Newstrom-Lloyd, L.E.; Foster, B.J.; Badger, P.H.; McLean, J.A. Winter 2016 honey bee colony losses in New Zealand. J. Apic. Res. 2018, 57, 278-291. [CrossRef]

12. Sperandio, G.; Simonetto, A.; Carnesecchi, E.; Costa, C.; Hatjina, F.; Tosi, S.; Gilioli, G. Beekeeping and Honey Bee Colony Health: A Review and Conceptualization of Beekeeping Management Practices Implemented in Europe. Sci. Total Environ. 2019, 696, 133795. [CrossRef]

13. Steinhauer, N.; Saegerman, C. Prioritizing changes in management practices associated with reduced winter honey bee colony losses for US beekeepers. Sci. Total Environ. 2021, 753, 141629. [CrossRef] [PubMed]

14. Meikle, W.G.; Weiss, M.; Maes, P.W.; Fitz, W.; Snyder, L.A.; Sheehan, T.; Mott, B.M.; Anderson, K.E. Internal Hive Temperature as a Means of Monitoring Honey Bee Colony Health in a Migratory Beekeeping Operation before and during winter. Apidologie 2017, 48, 666-680. [CrossRef]

15. De Guzman, L.I.; Simone-Finstrom, M.; Frake, A.M.; Tokarz, P. Comb irradiation has limited, interactive effects on colony performance or pathogens in bees, Varroa destructor and wax based on two honey bee stocks. Insects 2019, 10, 15. [CrossRef]

16. Shimshoni, J.A.; Sperling, R.; Massarwa, M.; Chen, Y.; Bommuraj, V.; Borisover, M.; Barel, S. Pesticide Distribution and Depletion Kinetic Determination in Honey and Beeswax: Model for Pesticide Occurrence and Distribution in Beehive Products. PLoS ONE 2019, 14, e0212631. [CrossRef]

17. El Agrebi, N.; Traynor, K.; Wilmart, O.; Tosi, S.; Leinartz, L.; Danneels, E.; de Graaf, D.C.; Saegerman, C. Pesticide and Veterinary Drug Residues in Belgian Beeswax: Occurrence, Toxicity, and Risk to Honey Bees. Sci. Total Environ. 2020, 745, 141036. [CrossRef]

18. Musinguzi, P.; Bosselmann, A.S.; Pouliot, M. Livelihoods-Conservation Initiatives: Evidence of Socio-Economic Impacts from Organic Honey Production in Mwingi, Eastern Kenya. For. Policy Econ. 2018, 97, 132-145. [CrossRef]

19. Wintermantel, D.; Odoux, J.; Chadœuf, J.; Bretagnolle, V. Organic Farming Positively Affects Honeybee Colonies in a Flower-poor Period in Agricultural Landscapes. J. Appl. Ecol. 2019, 56, 1960-1969. [CrossRef]

20. Goulson, D.; Nicholls, E.; Botías, C.; Rotheray, E.L. Bee declines driven by combined stress from parasites, pesticides, and lack of flowers. Science 2015, 347, 6229. [CrossRef]

21. Durant, J.L. Where Have All the Flowers Gone? Honey Bee Declines and Exclusions from Floral Resources. J. Rural Stud. 2019, 65, 161-171. [CrossRef]

22. Urbanowicz, C.; Baert, N.; Bluher, S.E.; Böröczky, K.; Ramos, M.; McArt, S.H. Low Maize Pollen Collection and Low Pesticide Risk to Honey Bees in Heterogeneous Agricultural Landscapes. Apidologie 2019, 50, 379-390. [CrossRef]

23. Gray, A.; Brodschneider, R.; Adjlane, N.; Ballis, A.; Brusbardis, V.; Charrière, J.D.; Chlebo, R.; Coffey, M.F.; Cornelissen, B.; da Costa, C.A.; et al. Loss rates of honey bee colonies during winter 2017/18 in 36 countries participating in the COLOSS survey, including effects of forage sources. J. Apic. Res. 2019, 58, 479-485. [CrossRef]

24. Schmolke, A.; Kearns, B.; O’Neill, B. Plant Guttation Water as a Potential Route for Pesticide Exposure in Honey Bees: A Review of Recent Literature. Apidologie 2018, 49, 637-646. [CrossRef] 
25. Pilling, E.; Campbell, P.; Coulson, M.; Ruddle, N.; Tornier, I. A Four-Year Field Program Investigating Long-Term Effects of Repeated Exposure of Honey Bee Colonies to Flowering Crops Treated with Thiamethoxam. PLoS ONE 2013, 8, e77193. [CrossRef] [PubMed]

26. Charrière, J.-D.; Imdorf, A.; Koenig, C.; Gallmann, S.; Kuhn, R. Do Sunflowers Influence the Development of Honey Bee, Apis mellifera, Colonies in Areas with Diversified Crop Farming? J. Apic. Res. 2010, 49, 227-235. [CrossRef]

27. Crailsheim, K.; Moosbeckhofer, R.; Brodschneider, R. Future of Honey Bees-Basic Research for Project for Honey Bee Health and Bee Protection. Final Report Poject 'Zukunft Biene' 2014-2018 Austria. 2018. Available online: https:/ /www.ages.at/en/topics/ environment/bees/research-projects-on-bees/future-of-honey-bees/ (accessed on 7 February 2020).

28. Bernal, J.; Martin-Hernandez, R.; Diego, J.C.; Nozal, M.J.; Gozalez-Porto, A.V.; Bernal, J.L.; Higes, M. An exposure study to assess the potential impact of fipronil in treated sunflower seeds on honey bee colony losses in Spain. Pest. Manag. Sci. 2011, 67, 1320-1331. [CrossRef] [PubMed]

29. Budge, G.E.; Garthwaite, D.; Crowe, A.; Boatman, N.D.; Delaplane, K.S.; Brown, M.A.; Thygesen, H.H.; Pietravalle, S. Evidence for Pollinator Cost and Farming Benefits of Neonicotinoid Seed Coatings on Oilseed Rape. Sci. Rep. 2015, 5, 12574. [CrossRef]

30. Balfour, N.J.; Al Toufailia, H.; Scandian, L.; Blanchard, H.E.; Jesse, M.P.; Carreck, N.L.; Ratnieks, F.L.W. Landscape Scale Study of the Net Effect of Proximity to a Neonicotinoid-Treated Crop on Bee Colony Health. Environ. Sci. Technol. 2017, 51, 10825-10833. [CrossRef]

31. Seeburger, V.C.; D’Alvise, P.; Shaaban, B.; Schweikert, K.; Lohaus, G.; Schroeder, A.; Hasselmann, M. The Trisaccharide Melezitose Impacts Honey Bees and Their Intestinal Microbiota. PLoS ONE 2020, 15, e0230871. [CrossRef]

32. Gregorc, A. Monitoring of Honey Bee Colony Losses: A Special Issue. Diversity 2020, 12, 403. [CrossRef]

33. Özcan, M.; Arslan, D.; Ali Ceylan, D. Effect of Inverted Saccharose on Some Properties of Honey. Food Chem. 2006, 99, 24-29. [CrossRef]

34. Nguyen, B.K.; Ribière, M.; vanEngelsdorp, D.; Snoeck, C.; Saegerman, C.; Kalkstein, A.L.; Schurr, F.; Brostaux, Y.; Faucon, J.-P.; Haubruge, E. Effects of Honey Bee Virus Prevalence, Varroa destructor Load and Queen Condition on Honey Bee Colony Survival over the Winter in Belgium. J. Apic. Res. 2011, 50, 195-202. [CrossRef]

35. Beyer, M.; Junk, J.; Eickermann, M.; Clermont, A.; Kraus, F.; Georges, C.; Reichart, A.; Hoffmann, L. Winter honey bee colony losses, Varroa destructor control strategies, and the role of weather conditions: Results from a survey among beekeepers. Res. Vet. Sci. 2018, 118, 52-60. [CrossRef] [PubMed]

36. Haber, A.I.; Steinhauer, N.A.; vanEngelsdorp, D. Use of chemical and nonchemical methods for the control of Varroa destructor (Acari: Varroidae) and associated winter colony losses in US beekeeping operations. J. Econ. Entomol. 2019, 112, 1509-1525. [CrossRef] [PubMed]

37. Giusti, M.; Sabelli, C.; Di Donato, A.; Lamberti, D.; Paturzo, C.E.; Polignano, V.; Lazzari, R.; Felicioli, A. Efficacy and Safety of Varterminator, a New Formic Acid Medicine against the Varroa Mite. J. Apic. Res. 2017, 56, 162-167. [CrossRef]

38. Maggi, M.D.; Amiani, N.D.; Uffinengo, S.R.; Rasesco, M.C.; Zawarski, N.S.; Itton, G.M.; Ariani, F.M.; Ammataro, D.S.; Uintana, S.Q.; Guaras, M.J. The susceptibility of Varroa destructor against oxalic acid: A study case. Bull. Insectol. 2017, 70, 39-44.

39. Gregorc, A.; Alburaki, M.; Sampson, B.; Knight, P.R.; Adamczyk, J. Toxicity of selected acaricides to honey bees (Apis mellifera) and Varroa (Varroa destructor Anderson and Trueman) and their use in controlling varroa within honey bee colonies. Insects 2018, 9, 55. [CrossRef]

40. Gregorc, A.; Adamczyk, J.; Kapun, S.; Planinc, I. Integrated Varroa Control in Honey Bee (Apis mellifera Carnica) Colonies with or without Brood. J. Apic. Res. 2017, 55, 253-258. [CrossRef]

41. Gregorc, A.; Sampson, B. Diagnosis of Varroa Mite (Varroa destructor) and Sustainable Control in Honey Bee (Apis mellifera) Colonies-A Review. Diversity 2019, 11, 243. [CrossRef]

42. Oddie, M.; Dahle, B.; Neumann, P. Reduced Postcapping Period in Honey Bees Surviving Varroa destructor by Means of Natural Selection. Insects 2018, 9, 149. [CrossRef] [PubMed]

43. Kamler, M.; Nesvorna, M.; Stara, J.; Erban, T.; Hubert, J. Comparison of Tau-Fluvalinate, Acrinathrin, and Amitraz Effects on Susceptible and Resistant Populations of Varroa destructor in a Vial Test. Exp. Appl. Acarol. 2016, 69, 1-9. [CrossRef] [PubMed]

44. Gracia, M.J.; Moreno, C.; Ferrer, M.; Sanz, A.; Peribáñez, M.Á.; Estrada, R. Field Efficacy of Acaricides against Varroa destructor. PLoS ONE 2017, 12, e0171633. [CrossRef] [PubMed]

45. Medici, S.K.; Maggi, M.D.; Sarlo, E.G.; Ruffinengo, S.; Marioli, J.M.; Eguaras, M.J. The Presence of Synthetic Acaricides in Beeswax and Its Influence on the Development of Resistance in Varroa destructor. J. Apic. Res. 2015, 54, 267-274. [CrossRef]

46. Wilmart, O.; Legrève, A.; Scippo, M.-L.; Reybroeck, W.; Urbain, B.; de Graaf, D.C.; Steurbaut, W.; Delahaut, P.; Gustin, P.; Nguyen, B.K.; et al. Residues in Beeswax: A Health Risk for the Consumer of Honey and Beeswax? J. Agric. Food Chem. 2016, 64, 8425-8434. [CrossRef]

47. Almecija, G.; Poirot, B.; Cochard, P.; Suppo, C. Inventory of Varroa destructor Susceptibility to Amitraz and Tau-Fluvalinate in France. Exp. Appl. Acarol. 2020, 82, 1-16. [CrossRef]

48. Li, J.L.; Cornman, R.S.; Evans, J.D.; Pettis, J.S.; Zhao, Y.; Murphy, C.; Peng, W.J.; Wu, J.; Hamilton, M.; Boncristiani, H.F.; et al. Systemic Spread and Propagation of a Plant-Pathogenic Virus in European Honeybees, Apis mellifera. mBio 2014, 5, e00898-13. [CrossRef] 
49. Meixner, M.D.; Francis, R.M.; Gajda, A.; Kryger, P.; Andonov, S.; Uzunov, A.; Topolska, G.; Costa, C.; Amiri, E.; Berg, S.; et al. Occurrence of Parasites and Pathogens in Honey Bee Colonies Used in a European Genotype-Environment Interactions Experiment. J. Apic. Res. 2014, 53, 215-229. [CrossRef]

50. Amiri, E.; Meixner, M.; Nielsen, S.L.; Kryger, P. Four Categories of Viral Infection Describe the Health Status of Honey Bee Colonies. PLoS ONE 2015, 10, e0140272. [CrossRef]

51. McMenamin, A.J.; Genersch, E. Honey Bee Colony Losses and Associated Viruses. Curr. Opin. Insect Sci. 2015, 8, 121-129. [CrossRef] [PubMed]

52. Genersch, E.; von der Ohe, W.; Kaatz, H.; Schroeder, A.; Otten, C.; Büchler, R.; Berg, S.; Ritter, W.; Mühlen, W.; Gisder, S.; et al. The German Bee Monitoring Project: A Long Term Study to Understand Periodically High Winter Losses of Honey Bee Colonies. Apidologie 2010, 41, 332-352. [CrossRef]

53. Cox-Foster, D.L.; Conlan, S.; Holmes, E.C.; Palacios, G.; Evans, J.D.; Moran, N.A.; Quan, P.-L.; Briese, T.; Hornig, M.; Geiser, D.M.; et al. A Metagenomic Survey of Microbes in Honey Bee Colony Collapse Disorder. Science 2007, 318, 283-287. [CrossRef] [PubMed]

54. Berthoud, H.; Imdorf, A.; Haueter, M.; Radloff, S.; Neumann, P. Virus Infections and Winter Losses of Honey Bee Colonies (Apis mellifera). J. Apic. Res. 2010, 49, 60-65. [CrossRef]

55. Highfield, A.C.; El Nagar, A.; Mackinder, L.C.M.; Nö̈ i $\frac{1}{2}$ l, L.M.-L.J.; Hall, M.J.; Martin, S.J.; Schroeder, D.C. Deformed Wing Virus Implicated in Overwintering Honeybee Colony Losses. Appl. Environ. Microbiol. 2009, 75, 7212-7220. [CrossRef]

56. Topolska, G.; Gajda, A.; Pohorecka, K.; Bober, A.; Kasprzak, S.; Skubida, M.; Semkiw, P. Winter colony losses in Poland. J. Apic. Res. 2010, 49, 126-128. [CrossRef]

57. Dainat, B.; Neumann, P. Clinical Signs of Deformed Wing Virus Infection Are Predictive Markers for Honey Bee Colony Losses. J. Invertebr. Pathol. 2013, 112, 278-280. [CrossRef]

58. Toplak, I.; Jamnikar Ciglenečki, U.; Aronstein, K.; Gregorc, A. Chronic Bee Paralysis Virus and Nosema Ceranae Experimental Co-Infection of Winter Honey Bee Workers (Apis mellifera L.). Viruses 2013, 5, 2282-2297. [CrossRef]

59. Retschnig, G.; Neumann, P.; Williams, G.R. Thiacloprid-Nosema Ceranae Interactions in Honey Bees: Host Survivorship but Not Parasite Reproduction Is Dependent on Pesticide Dose. J. Invertebr. Pathol. 2014, 118, 18-19. [CrossRef]

60. Doublet, V.; Labarussias, M.; de Miranda, J.R.; Moritz, R.F.; Paxton, R.J. Bees under stress: Sublethal doses of a neonicotinoid pesticide and pathogens interact to elevate honey bee mortality across the life cycle. Environ. Microbiol. 2015, 17, 969-983. [CrossRef]

61. Tesovnik, T.; Cizelj, I.; Zorc, M.; Čitar, M.; Božič, J.; Glavan, G.; Narat, M. Immune related gene expression in worker honey bee (Apis mellifera carnica) pupae exposed to neonicotinoid thiamethoxam and Varroa mites (Varroa destructor). PLoS ONE 2017, 12, e0187079. [CrossRef]

62. Straub, L.; Williams, G.R.; Vidondo, B.; Khongphinitbunjong, K.; Retschnig, G.; Schneeberger, A.; Chantawannakul, P.; Dietemann, V.; Neumann, P. Neonicotinoids and Ectoparasitic Mites Synergistically Impact Honeybees. Sci. Rep. 2019, 9, 8159. [CrossRef]

63. Di Prisco, G.; Cavaliere, V.; Annoscia, D.; Varricchio, P.; Caprio, E.; Nazzi, F.; Gargiulo, G.; Pennacchio, F. Neonicotinoid Clothianidin Adversely Affects Insect Immunity and Promotes Replication of a Viral Pathogen in Honey Bees. Proc. Natl. Acad. Sci. USA 2013, 110, 18466-18471. [CrossRef] [PubMed]

64. Coulon, M.; Schurr, F.; Martel, A.-C.; Cougoule, N.; Bégaud, A.; Mangoni, P.; Di Prisco, G.; Dalmon, A.; Alaux, C.; Ribière-Chabert, M.; et al. Influence of Chronic Exposure to Thiamethoxam and Chronic Bee Paralysis Virus on Winter Honey Bees. PLoS ONE 2019, 14, e0220703. [CrossRef] [PubMed]

65. Pohorecka, K.; Szczęsna, T.; Witek, M.; Miszczak, A.; Sikorski, P. The Exposure of Honey Bees to Pesticide Residues in the Hive Environment with Regard to Winter Colony Losses. J. Apic. Sci. 2017, 61, 105-125. [CrossRef]

66. Wade, A.; Lin, C.-H.; Kurkul, C.; Regan, E.R.; Johnson, R.M. Combined Toxicity of Insecticides and Fungicides Applied to California Almond Orchards to Honey Bee Larvae and Adults. Insects 2019, 10, 20. [CrossRef] [PubMed]

67. Gajger, I.T.; Vlainić, J.; Šoštarić, P.; Prešern, J.; Bubnič, J.; Smodiš Škerl, M.I. Effects on Some Therapeutical, Biochemical, and Immunological Parameters of Honey Bee (Apis mellifera) Exposed to Probiotic Treatments, in Field and Laboratory Conditions. Insects 2020, 11, 638. [CrossRef] [PubMed]

68. Schulz, M.; Łoś, A.; Grzybek, M.; Ścibior, R.; Strachecka, A. Piperine as a new natural supplement with beneficial effects on the life-span and defence system of honeybees. J. Agric. Sci. 2019, 157, 140-149. [CrossRef]

69. Tawfik, A.I.; Ahmed, Z.H.; Abdel-Rahman, M.F.; Moustafa, A.M. Influence of winter feeding on colony development and the antioxidant system of the honey bee, Apis mellifera. J. Apic. Res. 2020, 59, 752-763. [CrossRef]

70. Delaplane, K.S.; van der Steen, J.; Guzman-Novoa, E. Standard Methods for Estimating Strength Parameters of Apis mellifera Colonies. J. Apic. Res. 2013, 52, 1-12. [CrossRef]

71. Borsuk, G.; Ptaszyńska, A.A.; Olszewski, K.; Domaciuk, M.; Krutmuang, P.; Paleolog, J. A New Method for Quick and Easy Hemolymph Collection from Apidae Adults. PLoS ONE 2017, 12, e0170487. [CrossRef]

72. Lowry, O.H.; Rosebrough, N.J.; Farr, A.L.; Randall, R.J. Protein measurement with the Folin phenol reagent. J. Biol. Chem. 1951, 93, 265-275. [CrossRef]

73. Wang, T.; Riegger, A.; Lamla, M.; Wiese, S.; Oeckl, P.; Otto, M.; Wu, Y.; Fischer, S.; Barth, H.; Kuan, S.L.; et al. Water-Soluble Allyl Sulfones for Dual Site-Specific Labelling of Proteins and Cyclic Peptides. Chem. Sci. 2016, 7, 3234-3239. [CrossRef] [PubMed] 
74. Shumkova, R.; Balkanska, R.; Hristov, P. The Herbal Supplements NOZEMAT HERB ${ }^{\circledR}$ and NOZEMAT HERB PLUS ${ }^{\circledR}$ : An Alternative Therapy for N. ceranae Infection and Its Effects on Honey Bee Strength and Production Traits. Pathogens 2021, 10, 234. [CrossRef]

75. Charistos, L.; Parashos, N.; Hatjina, F. Long Term Effects of a Food Supplement HiveAlive ${ }^{\mathrm{TM}}$ on Honey Bee Colony Strength and Nosema Ceranae Spore Counts. J. Apic. Res. 2015, 54, 420-426. [CrossRef]

76. Al-Ghamdi, A.A.; Abou-Shaara, H.F.; Ansari, M.J. Effects of Sugar Feeding Supplemented with Three Plant Extracts on Some Parameters of Honey Bee Colonies. Saudi J. Biol. Sci. 2021, in press. [CrossRef] [PubMed]

77. Ptaszyńska, A.A.; Załuski, D. Extracts from Eleutherococcus Senticosus (Rupr. et Maxim.) Maxim. Roots: A New Hope Against Honeybee Death Caused by Nosemosis. Molecules 2020, 25, 4452. [CrossRef] [PubMed]

78. Archer, C.R.; Köhler, A.; Pirk, C.W.W.; Oosthuizen, V.; Apostolides, Z.; Nicolson, S.W. Antioxidant Supplementation Can Reduce the Survival Costs of Excess Amino Acid Intake in Honeybees. J. Insect Physiol. 2014, 71, 78-86. [CrossRef]

79. Stevanovic, J.; Stanimirovic, Z.; Simeunovic, P.; Lakic, N.; Radovic, I.; Sokovic, M.; Griensven, L.J.L.D.V. The Effect of Agaricus Brasiliensis Extract Supplementation on Honey Bee Colonies. An. Acad. Bras. Ciênc. 2018, 90, 219-229. [CrossRef]

80. Singh, M.; Pandey, N.; Agnihotri, V.; Singh, K.K.; Pandey, A. Antioxidant, Antimicrobial Activity and Bioactive Compounds of Bergenia Ciliata Sternb.: A Valuable Medicinal Herb of Sikkim Himalaya. J. Tradit. Complement. Med. 2017, 7, 152-157. [CrossRef] [PubMed]

81. Xu, D.-P.; Li, Y.; Meng, X.; Zhou, T.; Zhou, Y.; Zheng, J.; Zhang, J.-J.; Li, H.-B. Natural Antioxidants in Foods and Medicinal Plants: Extraction, Assessment and Resources. Int. J. Mol. Sci. 2017, 18, 96. [CrossRef]

82. Jain, C.; Khatana, S.; Vijayvergia, R. Bioactivity of secondary metabolites of various plants: A review. Int. J. Pharm. Sci. Res. 2019, 10, 494-498.

83. Rosado-Pérez, J.; Aguiñiga-Sánchez, I.; Arista-Ugalde, T.L.; Santiago-Osorio, E.; Mendoza-Núñez, V.M. The Biological Significance of Oxidative Stress, Effects of Fruits as Natural Edible Antioxidants. Curr. Pharm. Des. 2019, 24, 4807-4824. [CrossRef]

84. Moghrovyan, A.; Sahakyan, N.; Babayan, A.; Chichoyan, N.; Petrosyan, M.; Trchounian, A. Essential oil and ethanol extract of oregano (Origanum vulgare L.) from Armenian flora as a natural source of terpenes, flavonoids and other phytochemicals with antiradical, antioxidant, metal chelating, tyrosinase inhibitory and antibacterial activity. Curr. Pharm. Des. 2019, 25, 1809-1816. [CrossRef]

85. Geneva, M.; Kostadinov, K.; Filipov, S.; Kirova, E.; Stancheva, I. Analysis of the antioxidant capacity of lettuce growth at different fertilizer regimes. CR Acad. Bulg. Sci. 2021, 74, 1-10.

86. Alonso-Salces, R.M.; Cugnata, N.M.; Guaspari, E.; Pellegrini, M.C.; Aubone, I.; De Piano, F.G.; Antunez, K.; Fuselli, S.R. Natural Strategies for the Control of Paenibacillus larvae, the Causative Agent of American Foulbrood in Honey Bees: A Review. Apidologie 2017, 48, 387-400. [CrossRef]

87. Isidorov, V.A.; Buczek, K.; Segiet, A.; Zambrowski, G.; Swiecicka, I. Activity of Selected Plant Extracts against Honey Bee Pathogen Paenibacillus larvae. Apidologie 2018, 49, 687-704. [CrossRef]

88. Kirova, E.; Pecheva, D.; Simova-Stoilova, L. Drought response in winter wheat: Protection from oxidative stress and mutagenesis effect. Acta Physiol. Plant. 2021, 43, 8. [CrossRef]

89. Mao, W.; Schuler, M.A.; Berenbaum, M.R. A Dietary Phytochemical Alters Caste-Associated Gene Expression in Honey Bees. Sci. Adv. 2015, 1, e1500795. [CrossRef]

90. Gong, Y.; Diao, Q. Current Knowledge of Detoxification Mechanisms of Xenobiotic in Honey Bees. Ecotoxicology 2017, 26, 1-12. [CrossRef]

91. Liao, L.-H.; Wu, W.-Y.; Berenbaum, M. Impacts of Dietary Phytochemicals in the Presence and Absence of Pesticides on Longevity of Honey Bees (Apis mellifera). Insects 2017, 8, 22. [CrossRef]

92. Manjon, C.; Troczka, B.J.; Zaworra, M.; Beadle, K.; Randall, E.; Hertlein, G.; Singh, K.S.; Zimmer, C.T.; Homem, R.A.; Lueke, B.; et al Unravelling the Molecular Determinants of Bee Sensitivity to Neonicotinoid Insecticides. Curr. Biol. 2018, 28, 1137-1143.e5. [CrossRef] [PubMed]

93. Lazarov, S.B.; Veleva, P.; Zhelyazkova, I. Statistical Models for Assessing the Influence of Hygienic Behaviour of Worker Bees on the Level of Lysozyme and Total Protein Content in Their Haemolymph. Iran. J. Appl. Anim. Sci. 2020, 10, 365-373.

94. Leclercq, G.; Pannebakker, B.; Gengler, N.; Nguyen, B.K.; Francis, F. Drawbacks and Benefits of Hygienic Behavior in Honey Bees (Apis mellifera L.): A Review. J. Apic. Res. 2017, 56, 366-375. [CrossRef]

95. Reeves, A.M.; O’Neal, S.T.; Fell, R.D.; Brewster, C.C.; Anderson, T.D. In-Hive Acaricides Alter Biochemical and Morphological Indicators of Honey Bee Nutrition, Immunity, and Development. J. Insect Sci. 2018, 18, 8. [CrossRef]

96. Kunc, M.; Dobeš, P.; Hurychová, J.; Vojtek, L.; Poiani, S.B.; Danihlík, J.; Havlík, J.; Titěra, D.; Hyršl, P. The Year of the Honey Bee (Apis mellifera L.) with Respect to Its Physiology and Immunity: A Search for Biochemical Markers of Longevity. Insects 2019, 10, 244. [CrossRef] [PubMed]

97. Knoll, S.; Pinna, W.; Varcasia, A.; Scala, A.; Cappai, M.G. The honey bee (Apis mellifera L., 1758) and the seasonal adaptation of productions. Highlights on summer to winter transition and back to summer metabolic activity. A review. Livest. Sci. 2020, 235, 104011. [CrossRef]

98. Danihlík, J.; Aronstein, K.; Petřivalský, M. Antimicrobial Peptides: A Key Component of Honey Bee Innate Immunity: Physiology, Biochemistry, and Chemical Ecology. J. Apic. Res. 2015, 54, 123-136. [CrossRef] 
99. Liu, Y.; Wang, C.; Qi, S.; He, J.; Bai, Y. The Sublethal Effects of Ethiprole on the Development, Defense Mechanisms, and Immune Pathways of Honeybees (Apis mellifera L.). Environ. Geochem. Health 2021, 43, 461-473. [CrossRef] [PubMed]

100. Alaux, C.; Ducloz, F.; Crauser, D.; Le Conte, Y. Diet effects on honeybee immunocompetence. Biol. Lett. 2010, 6, 562-565. [CrossRef] [PubMed]

101. Orsavová, J.; Hlaváčová, I.; Mlček, J.; Snopek, L.; Mišurcová, L. Contribution of phenolic compounds, ascorbic acid and vitamin E to antioxidant activity of currant (Ribes L.) and gooseberry (Ribes uva-crispa L.) fruits. Food Chem. 2019, 284, 323-333. [CrossRef]

102. Perna, A.; Intaglietta, I.; Simonetti, A.; Gambacorta, E. A comparative study on phenolic profile, vitamin C content and antioxidant activity of Italian honeys of different botanical origin. Int. J. Food Sci. Technol. 2013, 48, 1899-1908. [CrossRef]

103. Farjan, M.; Dmitryjuk, M.; Lipiński, Z.; Biernat-Łopieńska, E.; Żółtowska, K. Supplementation of the honey bee diet with vitamin C: The effect on the antioxidative system of Apis mellifera carnica brood at different stages. J. Apic. Res. 2012, 51, 263-270. [CrossRef] 